University of Nebraska - Lincoln

DigitalCommons@University of Nebraska - Lincoln

Faculty Publications: Department of

Entomology

Entomology, Department of

December 1999

\title{
Amplification and methylation of an esterase gene associated with insecticide-resistance in greenbugs, Schizaphis graminum (Rondani) (Homoptera: Aphididae)
}

\author{
Midori Ono \\ University of Nebraska-Lincoln \\ Jeffrey J. Swanson \\ University of Nebraska-Lincoln \\ Linda M. Field \\ IACR-Rothamsted, Harpenden, Herts AL5 2JQ, UK \\ Alan L. Devonshire \\ IACR-Rothamsted, Harpenden, Herts AL5 2JQ, UK \\ Blair D. Siegfried \\ University of Nebraska-Lincoln, bsiegfried1@ufl.edu
}

Follow this and additional works at: https://digitalcommons.unl.edu/entomologyfacpub

Part of the Entomology Commons

Ono, Midori; Swanson, Jeffrey J.; Field, Linda M.; Devonshire, Alan L.; and Siegfried, Blair D., "Amplification and methylation of an esterase gene associated with insecticide-resistance in greenbugs, Schizaphis graminum (Rondani) (Homoptera: Aphididae)" (1999). Faculty Publications: Department of Entomology. 71.

https://digitalcommons.unl.edu/entomologyfacpub/71

This Article is brought to you for free and open access by the Entomology, Department of at DigitalCommons@University of Nebraska - Lincoln. It has been accepted for inclusion in Faculty Publications: Department of Entomology by an authorized administrator of DigitalCommons@University of Nebraska - Lincoln. 


\title{
Amplification and methylation of an esterase gene associated with in- secticide-resistance in greenbugs, Schizaphis graminum (Rondani) (Homoptera: Aphididae)
}

\author{
Midori Ono $^{a}$, Jeffrey J. Swanson ${ }^{a}$, Linda M. Field ${ }^{b}$, Alan L. Devonshire ${ }^{b}$, and Blair D. Siegfried ${ }^{*}$ \\ a Department of Entomology, 202 Plant Industry Building, University of Nebraska-Lincoln, Lincoln, NE 68583-0816, USA \\ ${ }^{b}$ IACR-Rothamsted, Harpenden, Herts AL5 2JQ, UK \\ *Corresponding author. Tel.: 402 472-211; Fax 402 472-4687; Email: bsiegfried1@unl.edu
}

\begin{abstract}
The greenbug aphid, Schizaphis graminum (Rondani) has developed resistance to organophosphorus insecticides by the over-production of esterases that have been classified as Type I and Type II. The first twenty $N$-terminal amino acids of the Type I esterase were determined and used to design an oligonucleotide, which in conjunction with an active site primer derived from conserved sequences of other insect esterases and two internal primers specific for esterases from another aphid species resulted in a $0.85 \mathrm{~kb}$ genomic DNA fragment from resistant greenbugs. This was extended by 5' RACE which provided approximately $1.2 \mathrm{~kb}$ of the $5^{\prime}$ end of the esterase gene. The 5' DNA sequence corresponded to 19 of the 20 known amino acids of the Type I esterase, with the last needing only a one base change (probably resulting from a PCR artifact). Furthermore, the sequence showed very close similarity to the amplified E4/FE4 esterase genes of Myzus persicae (Sulzer). A comparison of sequences suggested that the $S$. graminum gene has introns in the same positions as the first two introns of E4/FE4, with the second intron being considerably larger in $S$. graminum. Probing of Southern blots with the $0.85 \mathrm{~kb}$ esterase fragment showed that the gene encoding the Type I esterase is amplified 4- to 8-fold in resistant $\mathrm{S}$. graminum and that the amplified sequences contain 5-methylcytosine at $\mathrm{Msp} \mathrm{I} / \mathrm{HpaII}$ sites, again in agreement with previous findings for M. persicae genes.
\end{abstract}

Keywords: Schizaphis graminum, Esterase sequence, Insecticide resistance, Gene amplification

\section{Introduction}

The greenbug, Schizaphis graminum (Rondani), is a worldwide pest of small grains and sorghum. In the United States, outbreaks of $S$. graminum have largely been controlled through the deployment of greenbug-resistant cultivars. However, as $S$. graminum has evolved into different biotypes capable of overcoming many resistant cultivars, dependency on chemical control has increased. As a result, some populations of $S$. graminum have developed resistance to organophosphate insecticides, leading to field control failures.

Insecticide resistance in S. graminum is associated with elevated esterase activity, and two distinct patterns of enhanced esterase isozymes have been detected by native polyacrylamide gel electrophoresis stained with naphtho- lic esters mixed with Fast Garnet salts (Siegfried; Siegfried and Shufran). The Type I strain of resistant $S$. graminum produces a single esterase band that is undetectable in susceptible strains. Type II resistant aphids produce multiple, darkly staining esterase bands although one band, different from Type I, predominates. A combination of the two esterase banding patterns has not been observed in field populations.

It has been demonstrated that the Type I and Type II esterases can detoxify insecticides both in vivo and in vitro (Siegfried; Siegfried and Ono). The esterases in resistant strains are not active toward parathion but detoxify its oxidized form by sequestration rather than hydrolysis. Thus, resistance apparently results from the increased levels of esterases that can bind more insecticide molecules relative to the susceptible strain. 
The kinetic properties of partially purified esterase from Type II aphids suggest its overproduction based on a three-fold elevated $V_{\text {max }}$ and similar $K_{\mathrm{M}}$ in the resistant vs. susceptible strains with $\alpha$-naphthyl butyrate as substrate (Siegfried and Zera, 1994). However, a polyclonal antibody raised against the Type II esterase purified to homogenity resulted in signals of similar intensity in Western blots of total homogenates of susceptible, Type I, and Type II S. graminum (Siegfried et al., 1997b), indicating that the amount of the Type II esterase was similar in all strains. In contrast, an antiserum to esterase E4 of Myzus persicae (Sulzer) reacted with the esterase from the Type I $S$. graminum to give a more intense signal than with esterases from either susceptible or Type II strain (Siegfried et al., 1997b). These results suggest that the Type I greenbug esterase and esterase E4 of M. persicae have shared epitopes, and may be similar in structure. However, the Type II esterase did not cross-react with the E4 antiserum suggesting the two esterases are not as similar. Type I and Type II esterases share certain characteristics such as high sensitivity to inhibition by paraoxon and $\mathrm{HgCl}_{2}$ and partial inhibition with eserine while lacking reactivity toward acetylthiocholine (Siegfried and Ono, 1998). These data indicate that these estrases are B-esterases (Aldridge, 1953) and that a thiol goup is involved in catalysis or stability ( Ketterman et al., 1992). These characteristics are similarly observed with other resistance-conferring carboxylesterases such as esterases E4/FE4 of M. persicae and B1, A2 and B2 of Culex mosquitoes (Devonshire; Cuany; Ketterman and Karunaratne) suggesting that the underlying molecular mechanism(s) of esterase enhancement in S. graminum may be similar to that observed in these species, i.e. gene amplification (Devonshire and Field, 1991). Here we report the determination of the $N$-terminal amino acid sequence of the Type I esterase and its use to clone and identify part of the corresponding gene. This was used as a probe to demonstrate that the Type I esterase gene is both amplified and methylated in insecticide resistant $S$. graminum.

\section{Materials and methods}

\subsection{Insect strains and rearing}

The two parathion-resistant strains of $S$. graminum were established from field collections in areas of control failures with organophosphate insecticides, Type I from western Kansas and Type II from Sherman County, Texas (Ono et al., 1994). The susceptible colony was established from individuals collected from Lancaster County, Nebraska in August 1990. All colonies were maintained on two- to sixweek old sorghum (Funks G-522A) at $26^{\circ} \mathrm{C}$ with a $16: 8$ light:dark photoperiod. Apterous adults were collected in microcentrifuge tubes, immediately frozen in liquid nitrogen and stored at $-80^{\circ} \mathrm{C}$. Resistant strains of $M$. persicae were maintained as described previously (Hick et al., 1996).

\subsection{Characterization of purified type I esterase}

Purified Type I esterase was obtained by column chromatography and preparatory electrophoresis and the first 20 $\mathrm{N}$-terminal amino acids determined as described previously for Type II esterase (Siegfried et al., 1997a).

\subsection{Extraction and quantification of DNA}

DNA from each of the three strains of $S$. graminum (susceptible, Type I, and Type II) was extracted from up to $3 \mathrm{~g}$ of adult apterae by homogenizing in buffer $(100 \mathrm{mM} \mathrm{NaCl}$, $100 \mathrm{mM}$ EDTA, $100 \mathrm{mM}$ Tris $\mathrm{pH}$ 7.5, 0.5\% SDS), treating with proteinase $\mathrm{K}$ (at $55^{\circ} \mathrm{C}$ for at least $2 \mathrm{hrs}$ ) and RNase (20 $\min$ at $37^{\circ} \mathrm{C}$ ). The DNA was then phenol extracted, precipitated with ethanol (Sambrook et al., 1989) and resuspended in sterile water. DNA from $M$. persicae was extracted as previously described (Hick et al., 1996). DNA concentrations were determined by fluorimetry using Hoechst 33258 dye ( Labarca and Paigen, 1980).

\subsection{Amplification of genomic DNA by polymerase chain reaction ( $P C R$ )}

Primer 68 was a Type I-specific degenerate oligonucleotide 5'-GCIGGIGGITAYGARTAYAC-3' (where I denotes deoxyinosine, $\mathrm{Y} \mathrm{C}+\mathrm{T}$, and $\mathrm{R} \mathrm{A}+\mathrm{G}$ ), designed from part of the $\mathrm{N}$-terminal amino acid sequence of the Type I esterase (Ala, Gly, Gly, Tyr, Glu, Tyr, Thr, see results). A reverse primer 5'-TGAACCGAACTTGCT CCWGC-3' (where W denotes $\mathrm{A}+\mathrm{T}$ ) was designed from conserved active site sequences of other esterases, EF/FE4 of M. persicae, B1 of Culex mosquito, and esterase 6 of Drosophila melanogaster, and Primers 30 and 31 5'-GCATACCATATGCAAG$3^{\prime}$ and 5'-AGTATCCGCCGCCATG-3' (respectively) are specific for esterases E4/FE4 of M. persicae. The positions and directions of priming are given in Figure 1.

Primary PCR reactions contained $1.5 \mathrm{mM} \mathrm{MgCl} 2,0.2$ $\mathrm{mM}$ dNTPs, $100 \mathrm{ng}$ or $1 \mu \mathrm{M}$ each of primer 68 and the active site primer, $0.6-0.75$ unit of Taq polymerase, and ca. $200 \mathrm{ng}$ of template DNA in 1X polymerase buffer (as supplied by the manufacturer). A hot start was used with initial heating at $94^{\circ} \mathrm{C}$ for $3 \mathrm{~min}$ followed by the addition of the polymerase at $80^{\circ} \mathrm{C}$ and then 35 cycles of denaturing (at $94^{\circ} \mathrm{C}$ for $30 \mathrm{sec}$ ), annealing (at $40^{\circ} \mathrm{C}$ for $2 \mathrm{~min}$ ), and extension (at $72^{\circ} \mathrm{C}$ for $3 \mathrm{~min}$ ) with a final extension at $72^{\circ} \mathrm{C}$ for $10 \mathrm{~min}$. Secondary nested reactions using primers 30 and 31 were done as described above. 


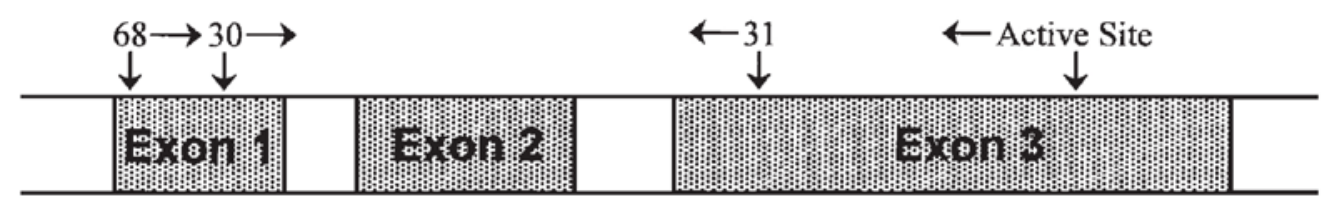

Figure 1. Location of oligonucleotides used as primers in nested-PCR. Priming sites are indicated relative to the first three exons of Myzus persicae esterases E4/FE4.

\subsection{Genomic digests and southern hybridization}

Genomic DNA $(20 \mu \mathrm{g})$ was digested with 100 units of restriction enzymes, electrophoresed in $0.8 \%$ agarose gels and blotted onto Hybond $\mathrm{N}^{+}$membrane (Amersham). Probing was done in $50 \%$ formamide, $5 \times \mathrm{SSC}, 0.05 \mathrm{M}$ sodium phosphate (pH 6.5), 5×Denhardt's, $0.1 \%$ SDS and 0.25 $\mu \mathrm{g} \mathrm{ml}^{-1}$ herring sperm DNA. Probes were labeled with $\alpha-$ $\left[\mathrm{P}^{32}\right] \mathrm{dCTP}$ by nick translation.

\subsection{Rapid amplification of $c D N A$ ends (RACE)}

Total RNA was extracted from aphids, which were either quick-frozen and stored at $-80^{\circ} \mathrm{C}$ or freshly collected. Twenty-five to thirty aphids were homogenized in $500 \mu \mathrm{l}$ buffer containing $8 \mathrm{M}$ guanidinium- $\mathrm{HCl}, 20 \mathrm{mM}$ MOPS and $20 \mathrm{mM}$ EDTA. This was centrifuged and the supernatant collected and extracted 3-4 times with phenol-chloroform (1:1). RNA was precipitated with ethanol, resuspended in sterile water, and quantified from its absorbance at $260 \mathrm{~nm}$. Its quality was judged by the presence of rRNA bands after electrophoresis in 1.5\% agarose gels.

The RNA was used to synthesize cDNA and extended by $5^{\prime}$ RACE using a kit from Life Technologies. The gene specific primers (MO1 5'-AGACAATCTTCCTGACC3', MO2 5'-GGCTTTACGGGTTGTGG-3', MO5 5'CTTCCCGGTATGGTGGC- $3^{\prime}$ ) were designed for the known internal cDNA sequence.

\subsection{DNA sequencing}

Fragments obtained from nested-PCR and RACE were sequenced by cycle sequencing using commercial dye termination kits (Applied Biosystems and Amersham).

\section{Results}

\subsection{The N-terminal sequence of type I esterase}

The first $20 \mathrm{~N}$-terminal amino acids were determined as: Ser, Asp, Thr, Pro, Lys, Val, Arg, Val, Asn, Ser, Gly, Asp, Ile, Ala, Gly, Gly, Tyr, Glu, Tyr, Thr.

\subsection{Isolation and characterization of part of a gene en- coding type I esterase}

Primary PCRs using primer 68 and the active-site oligonucleotide (see Materials and Methods) on genomic greenbug DNA resulted in many bands, a few of which were clearly visible ( Figure 2A, lanes 6-8). Secondary nested PCR with primers 30 and 31 gave one prominent $850 \mathrm{bp}$ band with $S$. graminum (lanes 2-4 in Figure 2A) and the expected $420 \mathrm{bp}$ band in the control M. persicae DNA (lane 5 in Figure 2A). Probing these PCR products with a fragment of the M. persicae $\mathrm{E} 4$ gene (GC112, an approximately $1.7 \mathrm{~kb}$ genomic fragment between the EcoRI site in exon 3 and the $K p n I$ site in intron 5 of the E4 gene) resulted in intense signals for $S$. graminum bands (Figure 2B) suggesting that the bands encoded esterase sequences. These genomic fragments were sequenced in both directions. However, sequencing failed to generate overlapping sequences in the middle.

Nevertheless, a translation of the nucleotide sequence at the $5^{\prime}$ end contained a fragment that matches the amino acid sequence encompassing the end of exon 1 through exon 2 of the E4/FE4 amino acid sequence of $M$. persicae while a translation towards the $3^{\prime}$ end of the obtained fragment resulted in an amino acid sequence that matched the end of intron 2 and part of exon 3 of E4/FE4 (L.M. Field, unpublished data). The Type I nucleotide sequence was somewhat different from susceptible and Type II because the Type I fragment did not align with the fragments amplified from the other strains while the susceptible and Type II fragments aligned with each other (data not presented). When the amino acid sequences translated from the $850 \mathrm{bp}$ Type I genomic fragment were compared with esterases E4/FE4 of $M$. persicae, the Type I sequence contained regions which aligned with the last several amino acids of exon 1 and exon 2 of E4/FE4. These alignments predicted an intron in $S$. graminum of the same size as that in the E4/FE4 genes (L.M. Field, unpublished data). The fragment from $S$. graminum was approximately $850 \mathrm{bp}$ in length (lanes 2-4; Figure 2A) and approximately $400 \mathrm{bp}$ larger than the corresponding $420 \mathrm{bp} \mathrm{E4/FE4}$ fragment ( lane 5; Figure 2A). This is believed to be due to a larger second intron in the greenbug gene. Thus, the sequence data demonstrated that the $850 \mathrm{bp}$ fragment is part of the gene encoding the Type I esterase of $S$. graminum. 

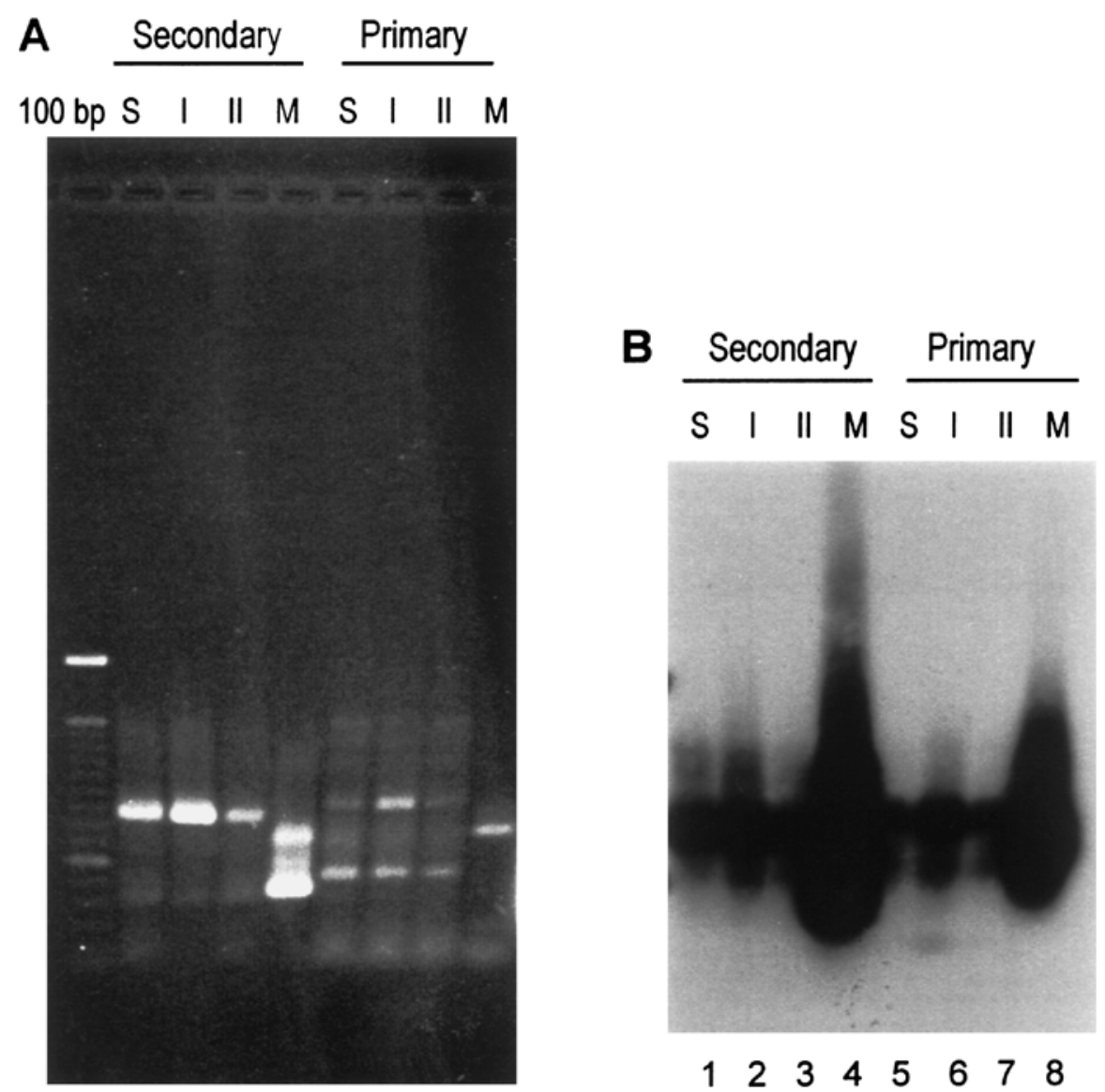

$\begin{array}{llllllll}1 & 2 & 3 & 4 & 5 & 6 & 7 & 8\end{array}$

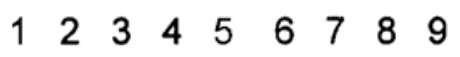

Figure 2. PCR products from DNA samples of susceptible (S), Type I (I) and Type II (II) S. graminum, and of M. persicae (M). The primary PCR was conducted using genomic DNA as template and a Type I-specific N-terminal primer and the active site primer derived from other esterases. The secondary PCR was conducted using the primary PCR products as template and two internal E4-specific primers (30 and 31). (A) Agarose gel stained with ethidium bromide. (B) Southern blot probed with GC112, an approximately $1.7 \mathrm{~kb}$ genomic fragment between the EcoRI site in exon 3 and the KpnI site in intron 5 of the E4 gene.

The sequence of the $850 \mathrm{bp}$ fragment was used to design primers suitable for $5^{\prime} \mathrm{RACE}$, and the consensus nucleotide sequence was obtained from at least three sequencing reactions. This consensus cDNA sequence, when translated into an amino acid sequence, aligned with the $5^{\prime}$ end of the E4 sequence of M. persicae, and therefore, the sequence appeared to contain the $5^{\prime}$ end of a greenbug esterase gene. The entire cDNA sequence and its inferred amino acid sequence are presented in Figure 3. From the start codon (ATG) there are 20 amino acids before the Ser, which starts a region where the predicted amino acid sequence matches that of the purified esterase from Type I greenbugs, and has close homology with the N-terminal sequence of E4 (Field et al., 1993). Of the 20 amino acids predicted by the cDNA, 19 are identical to the protein sequence. The only discrepancy is a Thr at position 3 of the protein sequence, which is an Ala in the predicted sequence. It would only require a one base change in the cDNA sequence to predict the correct amino acid (i.e. the first $\mathrm{G}$ of the GCG, Ala, changed to an A to get ACG for Thr) and this could result from a PCR artifact or through misidentification of the amino acid. Therefore, it is highly probable that the Type I fragment given in Figure 3 encodes a significant portion of the Type I esterase. This Type I sequence of $S$. graminum shares 73.0 and 72.5 percent identity with esterase FE4 and E4 of $M$. persicae, respectively, followed by esterase 6 from D. melanogaster (40 percent identity) at the amino acid level (Genetic Computer Group, 1997). At the nucleotide level, various forms of esterase 5 of Drosophila species share 58 to 60 percent identity with the Type I sequence of $S$. graminum. Not surprisingly, FE4 and E4 of M. persicae, another aphid species, scored highest in terms of shared identity (78.5) and base pair overlap (413 bases) (Genetics Computer Group, 1997). It is important to note that most of those similar to the Type I sequence are carboxyl-ester hydrolases (EC 3.1.1.1), and most of the proteins are esterase precursors. Sequence alignment for the purpose of comparison of four insect esterases, all of which except esterase 6 of D. melanogaster confer resistance to organophosphate insecticides, is presented in Fig- 


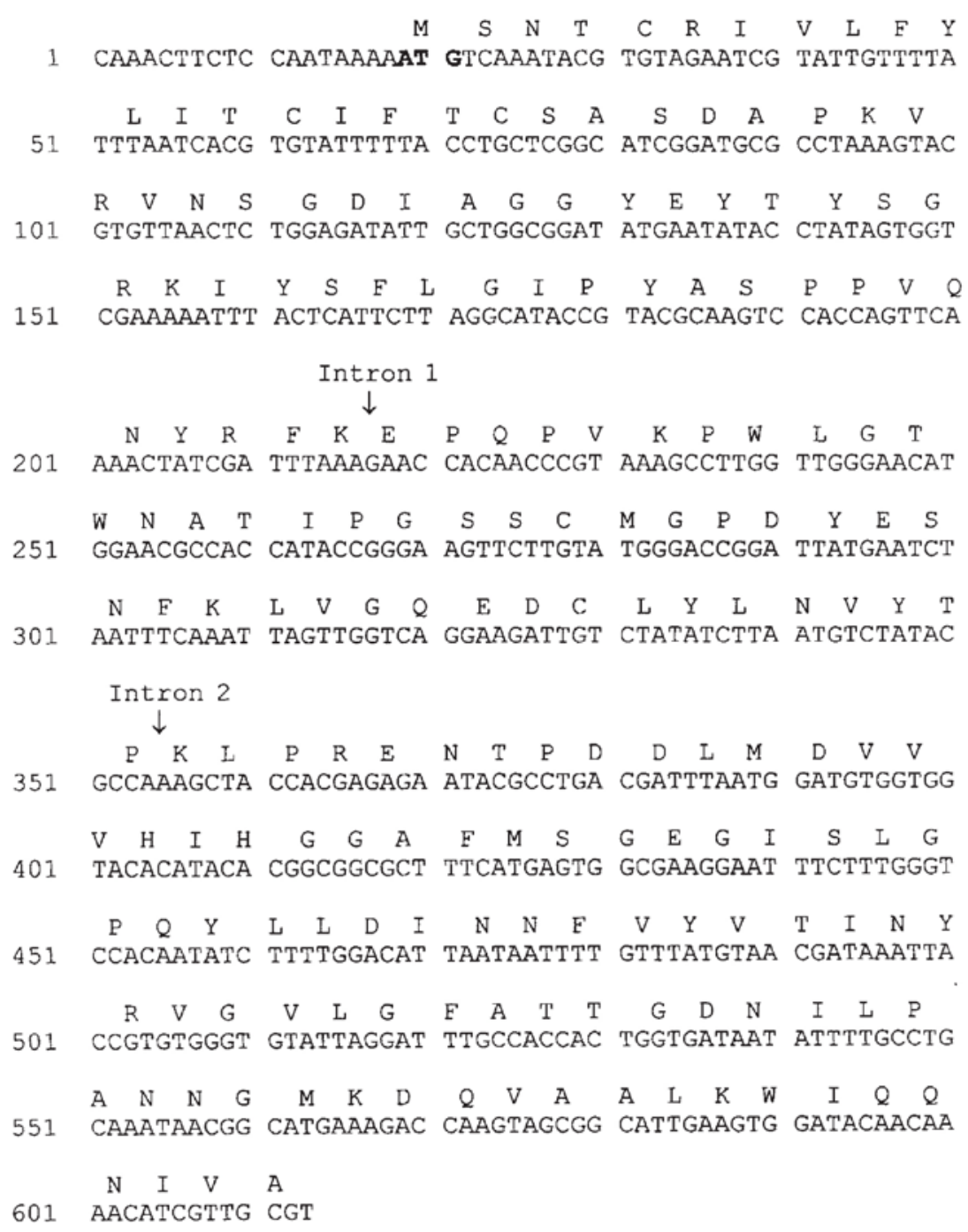

Figure 3. Nucleotide sequence of the $5^{\prime}$ end of the Type I greenbug esterase gene and its inferred amino acid sequence. The start codon is in bold and positions of introns indicated by arrows. Intron 1 and intron 2 are 75 and $550 \mathrm{bp}$ in size, respectively. The data are stored in the EMBL database, accession number Y17580.

ure 4. The only deletion the Type I esterase sequence has relative to the sequence of FE4 is at the beginning of the gene. Otherwise, the Type I and FE4 sequences have deletions at identical positions compared to Drosophila esterase 6 and Culex esterase B1. Areas where amino acid residues are highly conserved among all four sequences imply their importance in the folding, stability, or function as an esterase (Vaughan and Hemingway, 1995). The third position degeneracy is common in codons where the designated amino acid residues are identical.

\subsection{Identification of amplified, methylated esterase DNA sequences in greenbug DNA.}

Figure 5 shows the binding of the $850 \mathrm{bp}$ sequence of $S$. graminum (RI30) to genomic DNA digested with HindIII, MspI and HpaII. Susceptible and Type II aphids show the same banding patterns and band intensities with DNA extracts from the three strains of $S$. graminum indicating that there is no amplification of RI30-related sequences in the genome of Type II $S$. graminum. Furthermore, the $M s p I$ and HpaII fragments are the same in both strains showing that there is no methylation of sequences detected by the probe (HpaII does not cut CCGG sites if the internal C is 5-methylcytosine, see Field et al., 1989). In contrast, Type I aphids show more intense binding to a $6 \mathrm{~kb} H$ indIII fragment and to $5 \mathrm{~kb}$ and $1.5 \mathrm{~kb}$ fragments in HpaII and MspI digests, respectively. These results indicate that Type I aphids have amplified esterase sequences and the differences between MspI and HpaII show that these contain 5-methylcytosine at CCGG sites. This is analogous to the amplified esterase genes of M. persicae (Field and Hick).

In order to assess the relative copy number of esterase genes in $S$. graminum, different amounts of DNA, digested with $M s p I$, were probed with the RI30 fragment (Figure 6). 


\begin{tabular}{|c|c|c|c|c|c|c|c|c|c|c|c|c|c|c|c|c|c|c|c|}
\hline sg1 & $M$ & $S$ & $\mathrm{~N}$ & $T$ & C & $R$ & $I$ & $\mathrm{~V}$ & - & - & $L$ & $F$ & $\mathrm{Y}$ & $L$ & $I$ & $T$ & $c$ & I & - \\
\hline fe4 & $M$ & $\mathrm{~K}$ & $\mathrm{~N}$ & $\mathrm{~T}$ & C & G & I & $\mathrm{L}$ & L & $\mathrm{N}$ & $\mathrm{L}$ & $\mathrm{F}$ & L & $\mathrm{F}$ & I & $\mathrm{G}$ & $\mathrm{C}$ & $\mathrm{F}$ & - \\
\hline $\mathrm{dm} 6$ & & $M$ & $\mathrm{~N}$ & $Y$ & V & G & - & - & $\mathrm{L}$ & G & L & I & $I$ & $\mathrm{~V}$ & $L$ & $\mathrm{~S}$ & $\mathrm{C}$ & $\mathrm{L}$ & W \\
\hline sg1 & $\mathrm{T}$ & C & $S$ & A & $S$ & D & A & - & - & $P$ & - & $\mathrm{K}$ & $\mathrm{V}$ & $\mathrm{R}$ & $\mathrm{V}$ & $\mathrm{N}$ & $S$ & G & D \\
\hline fe4 & $\mathrm{T}$ & C & $S$ & A & $S$ & $N$ & $\mathrm{~T}$ & - & - & $\mathrm{P}$ & - & $\mathrm{K}$ & $\mathrm{V}$ & $Q$ & $\mathrm{~V}$ & $\mathrm{H}$ & $S$ & G & $E$ \\
\hline am 6 & G & $\mathrm{S}$ & $\mathrm{N}$ & A & $S$ & D & $\mathrm{T}$ & $D$ & D & $\mathrm{P}$ & L & $\mathrm{L}$ & $\mathrm{V}$ & $Q$ & L & $\mathrm{P}$ & $Q$ & G & $\mathrm{K}$ \\
\hline b1 & & & & & & M & $S$ & $\mathrm{~L}$ & $\mathrm{E}$ & $\mathrm{S}$ & L & $\mathrm{T}$ & $\mathrm{V}$ & $Q$ & $\mathrm{~T}$ & $\mathrm{~K}$ & $\mathrm{Y}$ & G & P \\
\hline sgl & A & G & $\mathrm{G}$ & $Y$ & $\mathrm{E}$ & $Y$ & $\mathrm{~T}$ & $Y$ & $S$ & G & $\mathrm{R}$ & $\mathrm{K}$ & I & $\mathrm{Y}$ & $S$ & $F$ & $L$ & G & $I$ \\
\hline fe4 & A & G & G & $\mathrm{F}$ & $E$ & $\mathrm{Y}$ & $\mathrm{T}$ & $\mathrm{Y}$ & $\mathrm{N}$ & G & $\mathrm{R}$ & $\mathrm{K}$ & I & $\mathrm{Y}$ & $\mathrm{s}$ & $\mathrm{F}$ & $\mathrm{L}$ & G & $I$ \\
\hline $\mathrm{dm} 6$ & $\mathrm{R}$ & G & $\mathrm{R}$ & $D$ & $\mathrm{~N}$ & G & $S$ & $Y$ & - & - & - & - & - & $\mathrm{Y}$ & $s$ & $Y$ & $\mathrm{E}$ & $\mathrm{s}$ & I \\
\hline b1 & $\mathrm{R}$ & G & $\mathrm{K}$ & $\mathrm{R}$ & $\mathrm{N}$ & V & $S$ & L & L & G & $Q$ & $E$ & $Y$ & $\mathrm{~V}$ & $S$ & $\mathrm{~F}$ & $Q$ & G & $I$ \\
\hline $\operatorname{sg} 1$ & $\mathbf{Y}$ & A & $S$ & $\mathrm{p}$ & P & V & $Q$ & $\mathrm{~N}$ & $\mathrm{Y}$ & $\mathbf{R}$ & $\mathbf{F}$ & $\mathrm{K}$ & $E$ & $\mathbf{P}$ & $Q$ & $\mathrm{P}$ & $\mathrm{V}$ & - & $\mathrm{K}$ \\
\hline $\mathrm{fe} 4$ & $\mathbf{Y}$ & $\mathrm{A}$ & $\mathrm{S}$ & P & P & V & $Q$ & $N$ & $\mathrm{~N}$ & $\mathbf{R}$ & $\mathbf{F}$ & $\mathrm{K}$ & $\mathrm{E}$ & $\mathbf{P}$ & $Q$ & $\mathrm{P}$ & $\mathrm{V}$ & - & $Q$ \\
\hline $\mathrm{dm} 6$ & $\mathbf{Y}$ & A & $\mathrm{E}$ & $\mathrm{p}$ & $\mathbf{P}$ & $T$ & $\mathrm{G}$ & $D$ & L & $\mathbf{R}$ & $F$ & $E$ & A & $\mathbf{P}$ & $E$ & $\mathbf{P}$ & $Y$ & $\mathrm{~K}$ & $Q$ \\
\hline b1 & $\mathbf{Y}$ & A & $\mathrm{R}$ & A & P & E & G & $E$ & $L$ & $\mathbf{R}$ & $\mathbf{F}$ & $\mathrm{K}$ & A & $\mathbf{P}$ & $\mathrm{V}$ & $\mathbf{P}$ & - & $\mathrm{P}$ & $Q$ \\
\hline sgl & W & L & $\mathrm{G}$ & $\mathrm{T}$ & W & $\mathrm{N}$ & A & $\mathbf{T}$ & $I$ & $P$ & $\mathrm{G}$ & $\mathrm{S}$ & $S$ & C & $M$ & $\mathrm{G}$ & $\mathrm{P}$ & D & - \\
\hline fe4 & W & L & G & V & W & $N$ & A & $T$ & $\mathrm{~V}$ & $\mathrm{p}$ & G & $S$ & A & C & L & G & $I$ & $E$ & - \\
\hline $\operatorname{dm} 6$ & W & $S$ & $D$ & I & F & D & A & $\mathbf{T}$ & $\mathrm{K}$ & $\mathrm{T}$ & $\mathrm{P}$ & $\mathrm{V}$ & $\mathrm{A}$ & C & L & $Q$ & W & $\mathrm{D}$ & $Q$ \\
\hline b1 & $\mathrm{w}$ & $\mathrm{T}$ & $E$ & $\mathrm{~T}$ & L & D & $C$ & $T$ & $Q$ & $Q$ & C & $E$ & $\mathrm{P}$ & C & $\mathrm{Y}$ & - & - & - & $\mathrm{H}$ \\
\hline 91 & $E$ & $S$ & $\mathrm{~N}$ & F & - & K & L & $\mathrm{V}$ & G & $Q$ & $\mathbf{E}$ & $\mathrm{D}$ & C & L & $\mathrm{Y}$ & L & $\mathrm{N}$ & $\mathrm{V}$ & $Y$ \\
\hline fe4 & G & $S$ & $\mathrm{G}$ & $S$ & - & $\boldsymbol{K}$ & I & I & G & $Q$ & $\mathbf{E}$ & D & $C$ & L & $F$ & L & $\mathrm{N}$ & $\mathrm{v}$ & $\mathrm{Y}$ \\
\hline$d m 6$ & $\mathrm{~T}$ & P & $G$ & A & $\mathrm{N}$ & $\mathrm{K}$ & $\mathrm{L}$ & $\mathrm{V}$ & G & $E$ & $\boldsymbol{E}$ & D & $\mathrm{C}$ & L & $\mathrm{T}$ & $\mathrm{V}$ & $S$ & $\mathrm{~V}$ & $Y$ \\
\hline b1 & $D$ & $\mathrm{R}$ & $\mathrm{R}$ & L & Q & $\mathrm{K}$ & I & $\mathrm{V}$ & G & $\mathrm{C}$ & $\mathbf{E}$ & $\mathrm{D}$ & $\mathrm{S}$ & L & $\mathrm{K}$ & $I$ & $\mathrm{~N}$ & $\mathrm{~V}$ & $\mathrm{~F}$ \\
\hline $\mathrm{sg} 1$ & $\mathrm{P}$ & $\mathrm{K}$ & I & P & $\mathrm{R}$ & $\mathrm{E}$ & $\mathrm{N}$ & $\mathrm{T}$ & $\mathrm{P}$ & $\mathrm{D}$ & D & $\mathrm{L}$ & $M$ & D & $\mathrm{V}$ & V & $\mathrm{V}$ & $\mathrm{H}$ & $I$ \\
\hline $\mathrm{fe} 4$ & $\mathrm{P}$ & $\mathrm{K}$ & L & P & Q & $\mathrm{E}$ & $\mathrm{N}$ & $S$ & A & G & D & L & $M$ & $\mathrm{~N}$ & $\mathrm{v}$ & I & $\mathrm{V}$ & $\mathrm{H}$ & $I$ \\
\hline $\mathrm{dm} 6$ & $\mathrm{P}$ & $\mathrm{K}$ & $\mathrm{N}$ & $\mathrm{S}$ & $\mathrm{K}$ & $\mathrm{R}$ & $\mathrm{N}$ & $\mathrm{S}$ & - & - & - & - & $F$ & $\mathrm{P}$ & $\mathrm{V}$ & $\mathrm{V}$ & A & $\mathrm{H}$ & I \\
\hline b1 & - & - & - & $\sim$ & $\mathrm{K}$ & $\mathrm{E}$ & I & $\mathrm{N}$ & $\mathrm{P}$ & $\mathrm{S}$ & $\mathrm{T}$ & $\mathrm{P}$ & $L$ & $\mathrm{P}$ & $\mathrm{v}$ & $\mathrm{M}$ & L & $Y$ & $I$ \\
\hline sg1 & G & G & A & F & M & $S$ & G & - & $E$ & G & $I$ & - & $\mathrm{S}$ & $L$ & $\mathbf{G}$ & $\mathrm{P}$ & $Q$ & $\mathrm{Y}$ & $L$ \\
\hline $\mathrm{fe} 4$ & G & G & G & $\mathrm{Y}$ & $\mathrm{Y}$ & F & G & - & $\mathrm{E}$ & $\mathrm{G}$ & I & - & $\mathrm{L}$ & $\mathrm{Y}$ & $\mathbf{G}$ & $\mathrm{P}$ & $\mathrm{H}$ & $\mathrm{Y}$ & L \\
\hline $\mathrm{dm} 6$ & G & G & A & $\mathrm{F}$ & M & F & $\mathbf{G}$ & - & A & A & W & - & $Q$ & $N$ & $\mathbf{G}$ & $\mathrm{H}$ & $\mathrm{E}$ & $\mathrm{N}$ & $\mathrm{V}$ \\
\hline b1 & G & G & G & F & $\mathrm{T}$ & $E$ & G & $\mathrm{T}$ & $S$ & G & $\mathrm{T}$ & $E$ & L & $\mathrm{Y}$ & $\mathbf{G}$ & $\mathrm{P}$ & $D$ & $F$ & L \\
\hline sg1 & $\mathrm{D}$ & $I$ & $\mathrm{~N}$ & $\mathrm{~N}$ & $F$ & V & $Y$ & $\mathrm{v}$ & $\mathrm{T}$ & I & $\mathrm{N}$ & $\mathbf{Y}$ & $\mathbf{R}$ & $\mathrm{V}$ & $\mathbf{G}$ & $\mathrm{V}$ & L & G & $\mathbf{F}$ \\
\hline fe4 & D & $\mathrm{N}$ & $\mathrm{N}$ & D & F & V & $Y$ & $\mathrm{v}$ & $S$ & I & $N$ & $\mathbf{Y}$ & $\mathbf{R}$ & L & G & $\mathrm{V}$ & L & $\mathbf{G}$ & $F$ \\
\hline $\mathrm{dm} 6$ & $\mathrm{R}$ & $\mathrm{E}$ & G & $\mathrm{K}$ & F & I & L & $\mathrm{V}$ & K & I & $\mathrm{S}$ & $\mathrm{Y}$ & $\mathbf{R}$ & $\mathrm{L}$ & G & $\mathrm{P}$ & L & G & $\mathrm{F}$ \\
\hline b1 & $Q$ & - & $\mathrm{K}$ & D & I & V & L & $\mathrm{V}$ & $\mathrm{S}$ & $\mathrm{F}$ & $\mathrm{N}$ & $\mathbf{Y}$ & $\mathbf{R}$ & I & G & A & L & $\mathbf{G}$ & $F$ \\
\hline sg1 & - & - & - & $\mathrm{T}$ & $\mathrm{T}$ & G & $D$ & $\mathrm{~N}$ & I & L & $\mathbf{P}$ & A & $\mathrm{N}$ & $\mathrm{N}$ & G & $M$ & $\mathrm{~K}$ & $D$ & Q \\
\hline fe4 & - & - & - & $S$ & $\mathrm{~T}$ & G & D & G & $\mathrm{V}$ & L & $\mathbf{P}$ & G & $\mathrm{N}$ & $\mathrm{N}$ & $\mathbf{G}$ & L & $\mathbf{K}$ & D & $Q$ \\
\hline $\mathrm{dm} 6$ & - & - & - & $S$ & $T$ & G & D & $\mathrm{R}$ & $\mathrm{D}$ & $L$ & $\mathbf{P}$ & $\mathrm{G}$ & $\mathbf{N}$ & $Y$ & G & L & $\mathrm{K}$ & D & Q \\
\hline b1 & $\mathrm{C}$ & $C$ & $Q$ & $S$ & $\mathrm{E}$ & Q & $D$ & G & V & - & $\mathbf{P}$ & G & $\mathrm{N}$ & $\mathrm{A}$ & G & L & $\mathrm{K}$ & $D$ & $Q$ \\
\hline sg1 & A & A & L & $\mathrm{K}$ & W & I & $Q$ & $Q$ & $\mathrm{~N}$ & I & V & A & & & & & & & \\
\hline fe4 & A & A & L & $\mathrm{K}$ & W & I & $Q$ & $Q$ & $\mathrm{~N}$ & I & V & A & F & G & G & $\mathrm{D}$ & $\mathrm{P}$ & & \\
\hline $\mathrm{dm} 6$ & L & A & L & $\mathrm{K}$ & W & I & K & $Q$ & $\mathbf{N}$ & I & A & $S$ & $\mathrm{~F}$ & G & G & $E$ & P & & \\
\hline b1 & $\mathrm{L}$ & A & I & $\mathrm{R}$ & W & V & L & $\mathrm{E}$ & $\mathbf{N}$ & I & $\mathrm{A}$ & A & $F$ & G & $\mathrm{G}$ & D & $\mathrm{P}$ & & \\
\hline
\end{tabular}

Figure 4. Sequence alignment of the amino acid sequences of four esterases. The sequences are aligned by hand using results of PILEUP analysis (Genetics Computer Group, 1997) and are Schizaphis graminum Type I esterase (sg1), Myzus persicae esterase FE4 (fe4), Drosophila melanogaster esterase 6 (dm6), and Culex pipiens esterase B1 (b1). Letters in bold denote amino acid residues conserved in the four sequences.

Signal intensities were compared for one fragment that was common to all three strains but appears to be amplified in Type I. The $M s p$ I digest of $1.25 \mu \mathrm{g}$ Type I DNA resulted in a band with signal intensity similar to the digest of $10 \mu \mathrm{g}$ susceptible DNA or $5 \mu \mathrm{g}$ Type II DNA. These results indicate that Type I individuals of S. graminum have 4- to 8fold more copies of the Type I esterase sequence than susceptible or Type II individuals. 


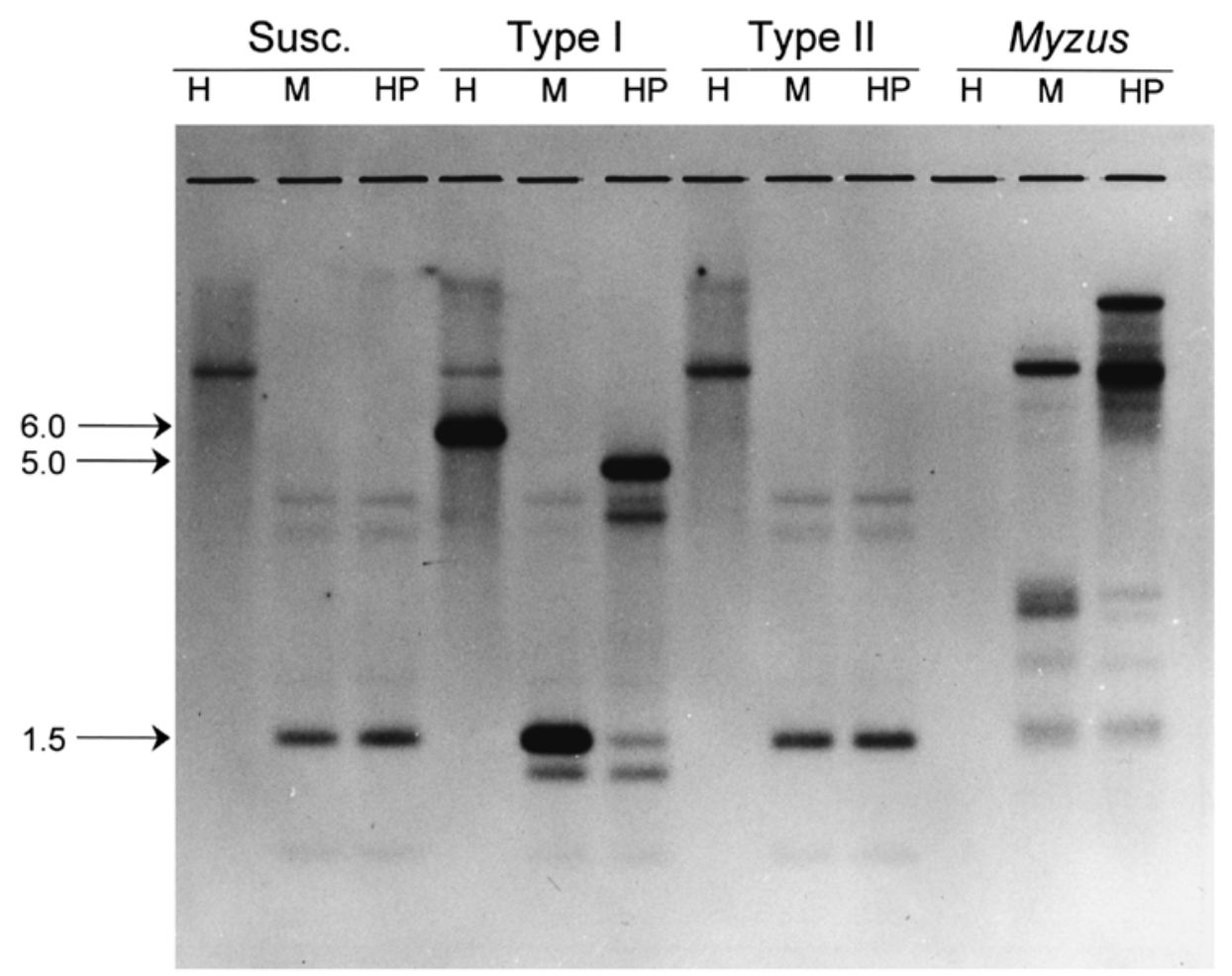

Figure 5. Genomic DNA from susceptible, Type I, and Type II greenbugs and M. persicae (Myzus) digested with HindIII (H), MspI (M), or HpaII (Hp) and probed with RI30, the 850 bp genomic fragment amplified from Type I greenbugs. Arrows indicate fragments amplified in the Type I genome (see text).

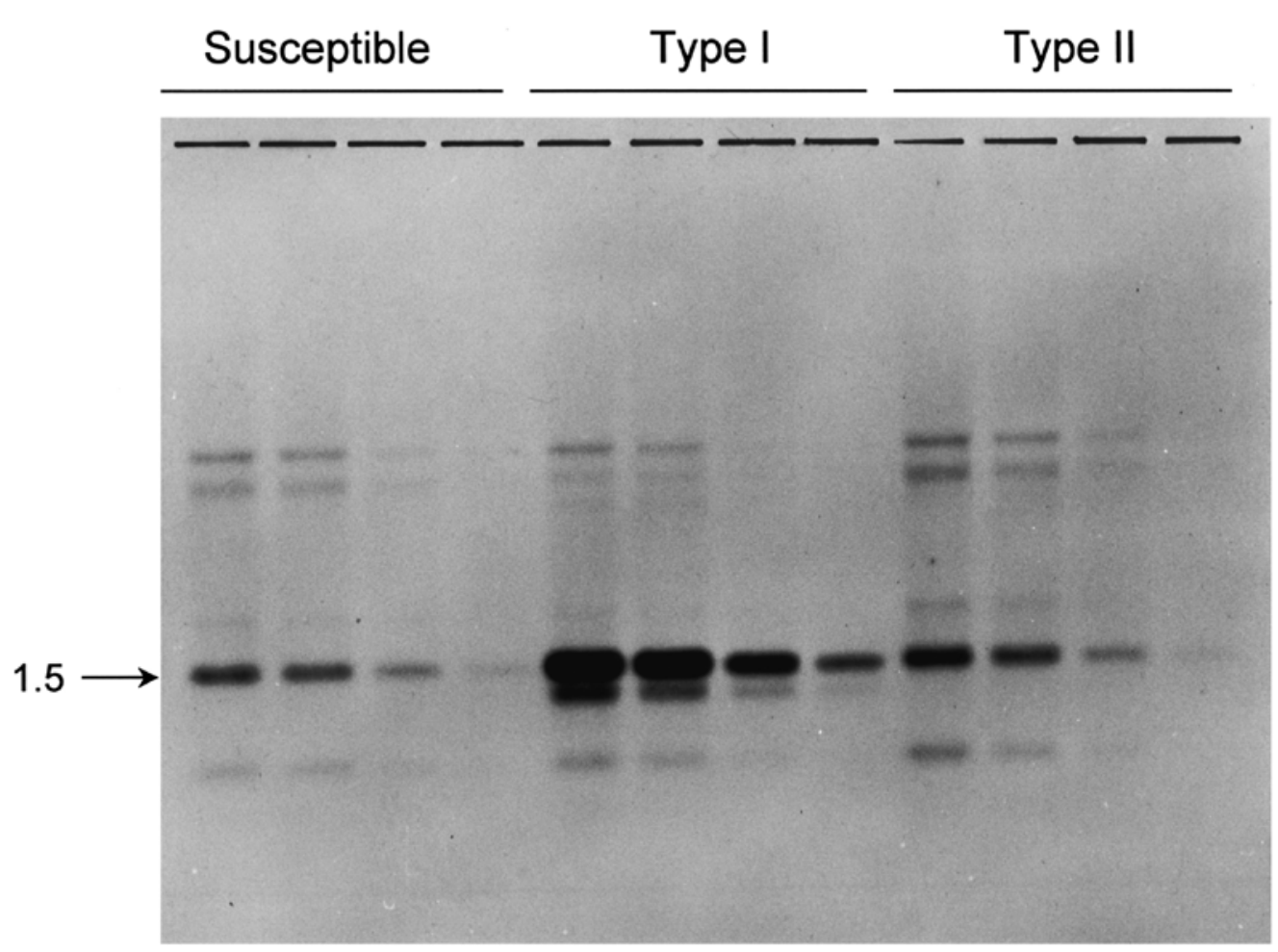

Figure 6. Genomic DNA from susceptible, Type I and Type II greenbugs, digested with MspI and probed with the RI30 Type I esterase fragment. The arrow indicates the fragment $(1.5 \mathrm{~kb})$ used to estimate the copy number. In each strain four lanes from the left to the right contain $10,5,2.5$, and $1.25 \mu \mathrm{g}$ DNA, respectively. 


\section{Discussion}

Gene amplification is a mechanism by which species can adapt rapidly to environmental changes such as exposure to drugs, pesticides, or other naturally occurring xenobiotics. In those organophosphate-resistant insects where gene amplification has been identified, individuals with multiple copies of esterase genes can express high levels of the enzyme to sequester insecticides before the molecules reach the target site. The present study shows gene amplification to be the molecular mechanism of organophosphate resistance in the Type I strain of $S$. graminum. Repeated Southern hybridization using the Type I esterase fragment showed no evidence for amplification of similar esterase sequences in the genome of the Type II strain. Therefore, Type II esterase appears to differ from the Type I esterase in primary structures, although esterase-mediated resistance has been identified from the Type II strain.

Both Type I and Type II esterases of $S$. graminum are similar in that they are B-esterases sensitive to inhibition by paraoxon and possess cysteine residues that enhance stability, a characteristic of serine hydrolases shared by other resistance-conferring esterases such as E4 and FE4 of M. persicae and esterases B1, A2, and B2 of $\mathrm{Cu}$ lex mosquitoes (Devonshire; Cuany and Vaughan). Further characterization with other insecticides and physiologically important substrates such as acylglycerols that possess ester bonds may be important to determining substrate specificities, cross-resistance potential, and possible physiological roles.

Sequences of the gene encoding Type I $S$. graminum confirm that this gene is very similar to the amplified esterase E4/FE4 genes of $M$. persicae, with 73 percent identity shared between inferred amino acid sequences. The DNA sequence obtained in this study did not include the active site serine; however, it is probable that this esterase is homologous to esterase E4/FE4 based on the shared identity and similarities between the first three exons. These are in agreement with immunological characterizations of esterases of $S$. graminum in which the E4 antiserum cross-reacted with the Type I esterase indicating shared epitopes and possible homology between esterase E4/FE4 and the Type I esterase (Siegfried et al., 1997b).

Our attempts to generate data on the Type II DNA sequence were not successful, because the fragments generated by PCR could not be identified as any part of an esterase gene based on nucleotide sequences from known esterase genes. Results of $\mathrm{N}$-terminal sequence analyses of the purified Type II esterase indicated differences in primary structure (Siegfried et al., 1997a). These results support the earlier experiments showing that the Type II esterase is immunologically different from the Type I esterase (Siegfried et al., 1997b).
Results of Southern hybridization experiments using the Type I fragment showed that the amplified esterase sequences in $S$. graminum were methylated as in $M$. persicae. There is a correlation between methylation and gene expression that is the direct opposite of the situation in vertebrates where methylation correlates with gene silencing (Holliday, 1996). Most invertebrate genomes that have so far been studied are predominantly nonmethylated ( Tweedie et al., 1997) and thus the role of methylation in Type I gene expression in S. graminum warrants further investigation.

Because of the similarities between esterase E4/FE4 of $M$. persicae and the Type I esterase of S. graminum, it is possible that genes may have evolved from a common ancestor and have since diverged. Base changes and size differences in the second intron between the two species support this hypothesis. The change in the sequence arrangement that resulted in amplification may be a relatively recent event that occurred independently in the two species. Because of the shared ancestral origin, similarities between genes could have resulted in similar amplification processes in response to selective pressures from exposure to organophosphate insecticides in both insects. The Type I gene appeared to have a relatively low copy number in the resistant individuals compared with Est $\mathrm{B} 1^{1}$ of Culex mosquitoes (Mouchès et al., 1990) but similar to that estimated in M. persicae (Field et al., 1996).

\section{Acknowledgements}

Authors thank Drs. David Taylor and Kenneth Pruess for their critical review of an earlier draft of the manuscript. We also thank Francisca Miota and Amanda Liggins who provided technical assistance for sample preparations. Partial funding was provided by the USDA North Central Pesticide Impact Assessment Program and University of Nebraska Center for Biotechnology. This is paper No. 12461 of the journal series of the University of Nebraska Agricultural Research Division and contribution No. 1013 of the Department of Entomology, University of Nebraska-Lincoln. IACR-Rothamsted receives grant-aided support from the Biotechnology and Biological Sciences Research Council of the United Kingdom.

\section{References}

Aldridge, W.N., 1953. Serun esterase. Biochem. J. 53, pp. 110-117.

Cuany, A., Handani, J., Bergé, J., Fournier, D., Raymond, M., Georghiou, G.P. and Pasteur, N., 1993. Action of esterase B1 on chlorpyrifos in organophosphate-resistant Culex mosquitoes. Pestic. Biochem. Physiol. 45, pp. 1-6. 
Devonshire, A.L. and Field, L.M., 1991. Gene amplification and insecticide resistance. Ann. Rev. Entomol. 36, pp. 1-23.

Devonshire, A.L. and Moores, G.D., 1982. A carboxylesterase with broad substrate specificity causes organophosphorus, carbamate and pyrethroid resistance in peach-potato aphids (Myzus persicae). Pestic. Biochem. Physiol. 18, pp. 235-246.

Field, L.M., Devonshire, A.L., Ffrench-Constant, R.H. and Forde, B.G., 1989. Changes in DNA methylation are associated with loss of insecticide resistance in the peach-potato aphid Myzus persicae (Sulz.). FEBS Lett. 243, pp. 323-327.

Field, L.M., Devonshire, A.L. and Tyler-Smith, C., 1996. Analysis of amplicons containing the esterase genes responsible for insecticide resistance in the peach-potato aphids Myzus persicae (Sulzer). Biochem. J. 313, pp. 543-547.

Field, L.M., Williamson, M.W., Moores, G.D. and Devonshire, A.L., 1993. Cloning and analysis of the esterase genes conferring insecticide resistance in the peach-potato aphid Myzus persicae (Sulzer). Biochem. J. 294, pp. 509-574.

Genetics Computer Group, 1997. Wisconsin Package, Version 9.1, Madison, Wisconsin, USA..

Hick, C.A., Field, L.M. and Devonshire, A.L., 1996. Changes in the methylation of amplified esterase DNA during loss and reselection of insecticide resistance in peach-potato aphids Myzus persicae. Insect Biochem. Molec. Biol. 26, pp. 41-47.

Holliday, R., 1996. DNA methylation in eukaryotes: 20 years on. In: Russo, V.E.A., Martienssen, R.A. and Riggs, A.D. Editors, 1996. Epigenetic Mechanisms of Gene Regulation Cold Spring Harbour Laboratory Press, Plainview (NY), pp. 5-27.

Ketterman, A.J., Jayawardena, K.G.I. and Hemingway, J., 1992. Purification and characterization of a carboxylesterase involved in insecticide resistance from the mosquito Culex quinquefasciatus. Biochem. J. 287, pp. 355-360.

Karunaratne, S.H.P.P., Jayawardena, K.G.I., Hemingway, J. and Ketterman, A.J., 1993. Characterization of a B-type esterase involved in insecticide resistance from the mosquito Culex Quinquefasciatus. Biochem. J. 294, pp. 575-579.

Labarca, C. and Paigen, K., 1980. A simple, rapid, and sensitive DNA assay procedure. Anal. Biochem. 102, pp. 344-352.

Mouchès, C., Pauplin, Y., Agarwal, M., Lemieux, L., Herzog, M., Abadon, M., Beyssat-Arnaouty, V., Hyrien, O., de Saint Vincent, B.R., Georghiou, G.P. and Pasteur, N., 1990. Characteriza- tion of amplification core and esterase B1 gene responsible for insecticide resistance in Culex. Proc. Natl. Acad. Sci. USA 87, pp. 2574-2578.

Ono, M., 1998. Molecular mechanisms of esterase-mediated insecticide resistance in the greenbug, Schizaphis graminum (Rondani) (Homoptera: Aphididae). A thesis, University of Nebraska..

Ono, M., Richman, J.S. and Siegfried, B.D., 1994. In vitro metabolism of parathion in susceptible and parathion-resistant strains of the greenbug, Schizaphis graminum (Rondani) (Homoptera: Aphididae). Pestic. Biochem. Physiol. 49, pp. 191-197.

Sambrook, J., Fritsch, E.F. and Maniatis, T., 1989. . Molecular cloning: a laboratory manual (2nd ed ed.), Cold Spring Harbor Laboratory Press, Plainview (NY).

Shufran, R.A., Wilde, G.E. and Sloderbeck, P.E., 1996. Description of three isozyme polymorphisms associated with insecticide resistance in greenbug (Homoptera: Aphididae) populations. J. Econ. Entomol. 89, pp. 46-50.

Siegfried, B.D. and Ono, M., 1993. Mechanisms of parathion resistance in the greenbug Schizaphis graminum (Rondani). Pestic. Biochem. Physiol. 45, pp. 24-33.

Siegfried, B.D. and Ono, M., 1993. Parathion toxicokinetics in resistant and susceptible strains of the greenbug (Homoptera: Aphididae). J. Econ. Entomol. 86, pp. 1317-1323.

Siegfried, B.D. and Zera, A.J., 1994. Partial purification and characterization of a greenbug (Homoptera: Aphididae) esterase associated with resistance to parathion. Pestic. Biochem. Physiol. 49, pp. 132-137.

Siegfried, B.D., Ono, M. and Swanson, J.J., 1997. Purification and characterization of a carboxylesterase associated with organophosphate resistance in the greenbug, Schizaphis graminum (Homoptera: Aphididae). Arch. Insect Biochem. Physiol. 36, pp. 229-240.

Siegfried, B.D., Swanson, J.J. and Devonshire, A.L., 1997. Immunological detection of greenbug (Schizaphis graminum) esterases associated with resistance to organophosphate insecticides. Pestic. Biochem. Physiol. 57, pp. 165-170.

Tweedie, S., Charlton, J., Clark, V. and Bird, A., 1997. Methylation of genomes and genes at the invertebrate- vertebrate boundary. Mol. Cell. Biol. 17, pp. 1469-1475.

Vaughan, A. and Hemingway, J., 1995. Mosquito carboxylesterase Est $\alpha 2^{1}\left(\mathrm{~A}_{2}\right)$. J. Biol. Chem. 270, pp. 17044-17049. 